\title{
DISTRIBUTION OF PLUTONIUM AND AMERICIUM \\ IN OCCUPATIONALLY EXPOSED HUMANS \\ AS FOUND FROM AUTOPSY SAMPLES
}

\section{by}

C. R. Lagerquist

S. E. Hammond

D. L. Bokowski

D. B. Hylton, M. D.

This report was prepared as an account of work sponsored by the United States Government. Neither the Unlted States nor the United States Atomic Energy Commission, nor any of their employees, nor any of their contractors, subcontractors, or their employees, makes any warranty, express or implied, or assumes any legal liability or responsibility for the accuracy, comlegal liability or responsibility for the accuracy, com-
pleteness or usefulness of any information, apparatus, pleteness or usefulness of any information, apparatus,
product or process disclosed, or represents that its use would not infringe privately owned rights.

Dow Chemical U. S. A. Rocky Flats Division

May 1, 1972 


\section{DISCLAIMER}

This report was prepared as an account of work sponsored by an agency of the United States Government. Neither the United States Government nor any agency Thereof, nor any of their employees, makes any warranty, express or implied, or assumes any legal liability or responsibility for the accuracy, completeness, or usefulness of any information, apparatus, product, or process disclosed, or represents that its use would not infringe privately owned rights. Reference herein to any specific commercial product, process, or service by trade name, trademark, manufacturer, or otherwise does not necessarily constitute or imply its endorsement, recommendation, or favoring by the United States Government or any agency thereof. The views and opinions of authors expressed herein do not necessarily state or reflect those of the United States Government or any agency thereof. 


\section{DISCLAIMER}

Portions of this document may be illegible in electronic image products. Images are produced from the best available original document. 


\begin{abstract}
Nineteen cases are discussed where tissues were obtained from autopsy and analyzed radiochemically for plutonium and americium.

Distribution patterns varied greatly from case to case, depending on: the mode of entry, the chemical form, the length of time since exposure, and perhaps many other. parameters as well. A typical distribution was not found, but on the average the lung and tracheal-bronchiai iympin nodes had the highest concentration of material followed by the liver, the bones, and finally the other tissues.
\end{abstract}


INTRODUCTION

We determine internal deposition of plutonium and americium in our workers by measuring amounts in the urine and by direct measurements using our body counter. Both of these methods have been described before; by us ${ }^{1,2}$ and by others $3,4,5$. Both of these methods involve possible errors. The best test of their accuracy must come through the quantitative determination of these nuclides in the tissues at the time of autopsy. When whole organs are not sampled, this method too involves possible errors, but it is the best measure of the true deposition available.

Two projects are currently measuring plutonium deposition from fallout through autopsy programs ${ }^{6,7}$ but only a few cases have been reported on the analysis of tissues from occupationally exposed workers. The first was reported by Foreman ${ }^{8}$, we have reported two 9,10 , the $\mathrm{H}-5$ group at Los Alamos has recently collected data on their cases ${ }^{11}$, and Norwood ${ }^{12}$ has recently reported two Hanford cases along with twelve Rocky Flats cases that have been reported to the U. S. Transuranium Registry.

This report also includes these twelve cases, along with seven more that have been completed since then. An attempt is made here to show some trends from the nineteen Rocky Flats cases, but thes e trends must be considered tentative because of the small number of ases involved. 
We first started analyzing tissue samples at autopsy in 1967 when an employee with a record of exposure to plutonium died from a heart attack. 'An autopsy was performed and we asked the pathologist if we could analyze some tissue samples for plutonium as a logical extension of the autopsy. We asked to do this mainly for a check on our accuracy of estimating plutonium in the system from urine analysis.

Since that time, the U. S. Transuranium Registry has been formed. This has given our employees an opportunity to volunteer for this program. It has also helped to get permission for autopsy from the next of kin because of the Registry's national stature.

EXTRAPOLATING TO WHOLE BODY CONTENT OF PLUTONIUNI

Extrapolating the findings from portions of organs to whole organs, and from whole organs to the total body can be done in different ways. Until more is known about variations in concentration from one area to another, no single method can be considered correct.

In most cases, we analyzed the entire liver, lung, spleen, heart and kidneys. The total content of the skeleton was determined by averaging the concentrations found in small samples of ribs, sternum, and vertebra and then extrapolating linearly to 10,000 grams (the skeletal weight of the standard man).

An estimate of the amount in "remaining organs" was made by. using the lowest concentration found in the soft tissues (Table I) and extrapolating to the remaining body weight using the man's last known weight. This calculation is the most suspect and 
probably contains large errors. Whole bodies will have to be studied before we know better how to treat this portion, which is about $85 \%$ of the body weight.

Table I shows the concentrations found in the major organs for the nineteen cases analyzed to date. Table II shows this information for americium concentrations on some of the cases.

COMPARISON BETWEEN SYSTEMIC BURDENS CALCULATED FROM URINE RESULTS AND EXTRAPOLATED AMOUNTS FROM AUTOPSY

Table III shows the comparison between the systemic burden calculated from urine analyses and the extrapolated amount found at autopsy. In both cases, the systemic burden does not include amounts in the lung or wound sites because they are considered reservoirs that cannot be measured by urine sampling ${ }^{\text {is }}$. These reservoirs are measured separately with a wound counter and a lung counter and are considered part of the whole body burden.

\section{DISTRIBUTION OF PLUTONIUM BY CONCENTRATION}

Average concentration in the major organs for these nineteen cases is shown in Figure 1. This averaging was done so that major trends could be shown, but it does not mean to imply that the distribution should be the same in all occupationally exposed workers. On the contrary, it is known that this distribution will vary from case to case, depending on mode of entry, chemical form, particle size, length of time since exposure, age, and perhaps other parameters as well. 
In order that any averaging can be done, we must assume these differences are small in most cases.

The averaging was accomplished by first calculating a systemic burden of plutonium based on the autopsy findings (Table III). This systemic burden does not include amounts found in wounds or in lungs. After this is determined for each case, it is used to adjust the concentrations found in the individual organs to the amount that would be there from an exposure of one maximum permissible systemic burden (MPSB), or .04 $\mathrm{\mu Ci}$. After each case is so adjusted, numerical averaging is done for each of the major organs.

The lung and tracheal-bronchial lymph node results for Cases F, L, and $\mathrm{N}$ were not included in this average because they were known to be exposures via inhalation to high-fired oxide. It is felt that these cases will be the exception and should not be included when looking at typical occupational exposures. Also, the tracheal-bronchial lymph node result from Case $G$ was arbitrarily excluded because it was much higher than the others.

In Cases $Q, R$, and $S$ the pulmonary lymph nodes were separated from the lung tissue. The concentrations of plutonium are higher in these nodes than in the other lung tissue, but no average was reported because of the small number of cases involved.

Cases $Q$ and $S$ were excluded from the averaging because the systemic burdens were too low, i. e., less than .3\% MPSB. 
Americium results are reported here (Table II) but no general conclusion can be made from them. They are included because $\mathrm{Am}^{241}$ is used as a tracer of plutonium in our body counter ${ }^{2}$. The results are hard to interpret because of their low concentrations and because the plutonium to americium ratios were different in the exposure material.

SUMMARY

Twelve of the nineteen cases reported here had no known record of plutonium exposure based on their urine results. All of these had some detectable plutonium in their organs, but generally an amount that is representative of less than $1 \%$ of the MPSB. The seven cases where a systemic burden was calculated from urine results had a higher calculated systemic burden than the amount found to be there from autopsy samples..

The plutonium concentrations, and thus dose rates, were on the average much higher in the lungs and tracheal-bronchial lymph nodes than on any other single organ. 
1. S. E. Hammond and E. A. Putzier, Health Physics 10, 6 (1964)

2. M. R. Boșs and J. R. Mann, Health Physics 13, 259 (1967)

3. E. E. Campbell and W. D. Moss, Health Physics 11, 737 (1965)

4. W. S. Snyder, Health Physics 8 , 6 (1962)

5. J. N. P. Lawrence, Health Physics 8,1 (1962)

6. I. C. Nelson et. al., AEC Report BNWL-SA-4077 (1971)

7. E. E. Campbell, et al., AEC Report LA 4875 (1972)

8. H. Foreman, Health Physics 8,735 (1962)

9. C. R. Lagerquist et. al., AIHA Journal 30, 417 (1969)

10. C. R. Lagerquist et. al., to be published in Health Physics

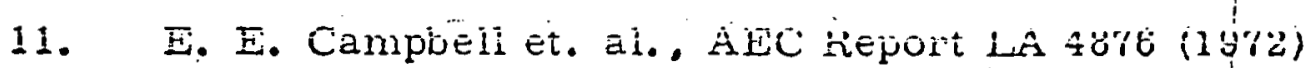

12. W. D. Norwood, to be published 


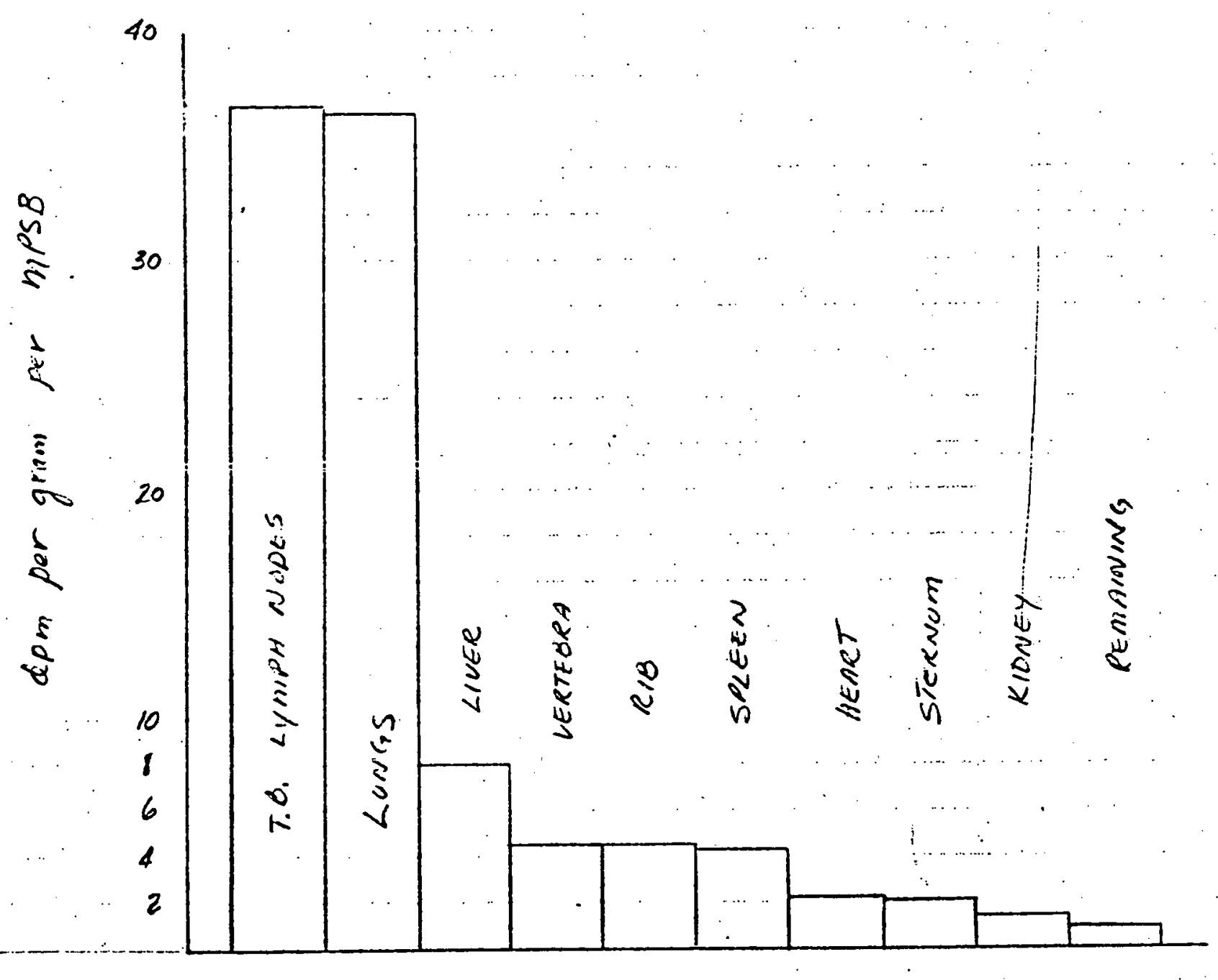

FIGURE 1. AUERAGE (CNGERTRAIIOAS OF PLICANGM FiUnd IN MAJER ORGAIS

$-8-$ 
Concentrations of Plutonium $\left(\mathrm{Pu}^{239}\right.$ and $\left.\mathrm{Pu}^{240}\right)$ in Disintegrations per Minute per Gram T. $B$.

La: iver Lung Lymph Node Rib Sternum Vertebra Heart Spleen Kidney Thyroid Other

\begin{tabular}{|c|c|c|c|c|c|c|c|c|c|c|}
\hline .319 & .210 & 1.37 & .107 & .085 & .145 & -- & 0 & 0 & -- & 1.003 \\
\hline 0 & .014 & 0 & 0 & .002 & - & .002 & .008 & 0 & $\ldots$ & -- \\
\hline .039 & .350 & .500 & .015 & -- & $\cdots$ & .018 & .015 & $.002^{\dagger}$ & -- & -- \\
\hline $.039^{\dagger}$ & Lost & -- & -- & 0 & -- & - & .600 & .045 & -- & $=-$ \\
\hline .039 & $\therefore 147$ & .108 & -- & 0 & - & - & .029 & $.010^{\dagger}$ & - & -- \\
\hline .310 & $97.6^{\ddagger}$ & $.850^{\ddagger}$ & .171 & - & - & $.023^{\dagger}$ & .180 & .028 & - & 027 \\
\hline .250 & 2.69 & $16.6^{\ddagger}$ & .037 & .008 & -- & - & $.014^{\dagger}$ & .017 & -- & \\
\hline .031 & .141 & .179 & .148 & .005 & -- & -- & .006 & $.003^{\dagger}$ & -- & -- \\
\hline
\end{tabular}

$9.40 \quad 4.05$

.012 .041

3.40

$-7.20$

$\begin{array}{llll}-- & 2.60 \quad .700^{\dagger}\end{array}$

$\mathbf{J}$

K

$.240 \quad 1.69 \quad .950$

$.0 \quad .009$

-. $.010 \quad .003^{+} .015$

.020

L $\quad .0605 .93^{ \pm}$

$2.3^{3}$

M $\quad .015 \quad .004$

.034

.040

$-.010^{+}$

.20

$.010^{t}$

$.080 \quad 49.10$

N .297

$11: 6^{\ddagger}$

$.034 \quad .007$

- $\quad . \quad .020 \quad .020^{+}$

- $\quad 1.009^{+}$

0.014

$\therefore \quad 016$

$.052 .008^{\dagger}$

$5.003^{\dagger}$

.297 ,

$.028 \quad .027 \quad .06$

0

$.032 \quad .004$

.030

1.05

$.104 \quad .077$

-. .003

$.006^{+} .017$

6.091

.008

.034

0

0.008

$.002^{\dagger} \quad .009$

-. $\quad 5006$

$.008 .262 \quad .80$

$0 \quad .002$

$0 \quad .047$

$.007 .001^{\dagger}$

0 $\quad .275$

.011 .083

0

0

0

$0.007^{\dagger}$

- 6.16

S

Lost .027 .063

$0 \quad 0$

0

0

$0 \quad 6,19$

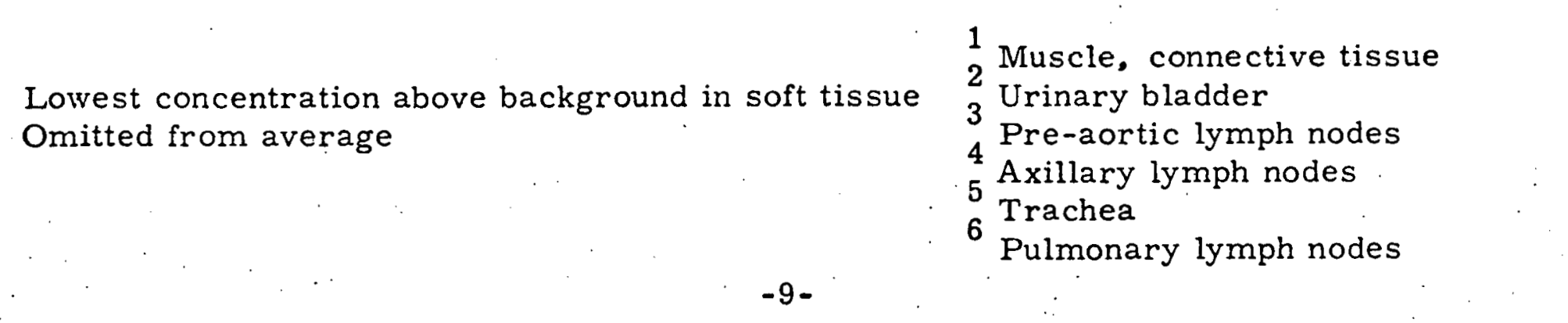


TABLE II

Concentrations of Americium ${ }^{241}$ in Disintegrations per Minute per Gram

T. B.

Jase Liver Lung Lymph Node Rib Sternum Vertebra Heart Spleen Kidney Thyroid Other

A $\quad .006 \quad .001$

C $\quad .046 \quad .031$

$\mathrm{F} \quad .046 \quad .55$

G $\quad .082 \quad .170$

$\begin{array}{cc}-- & -- \\ .65 & -- \\ .19 & .03 \\ 0 & 0\end{array}$

$.019 \quad .026$

0

I $.24 \cdot .20$

1.1

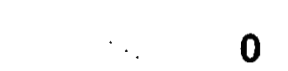

K .009 .050

.07

$-$

.57

L $\quad .007 \quad .126$

$.27 \quad .005$

.003
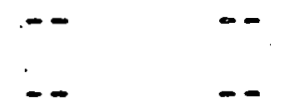

--
--
0

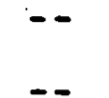

$\begin{array}{lll}\mathrm{M} & 0 & .003\end{array}$

0

$\mathrm{N} \quad .046$

.80

0

0

0

$-$

- 0

$\therefore$

O $\quad .002 \quad .004$

-

.002

-- $\quad--$

0

.013

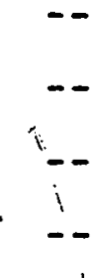

$\mathrm{P} \quad .002$

.006

0

$-$

$-$

.05

.015

-. .002

$.003 \quad .002$

0

1.42

Q $\quad .001$

$0 \quad 0$

-.

-- $\quad .002 \quad 0$

--

R $\quad .001 \quad .004$

0 ..

0

-. .002

0

0

0

$\begin{array}{llll}0 & .002 & 0 & 0\end{array}$

-. $001 \quad .003$

2.15

0

.004 .002

.02

${ }^{3} 0$

0

-- 0

0

0

.007

0

.091

0

0

2.28

Axillary lymph nodes

2

Pulmonary Lymph Nodes

Brain 
TABLE III

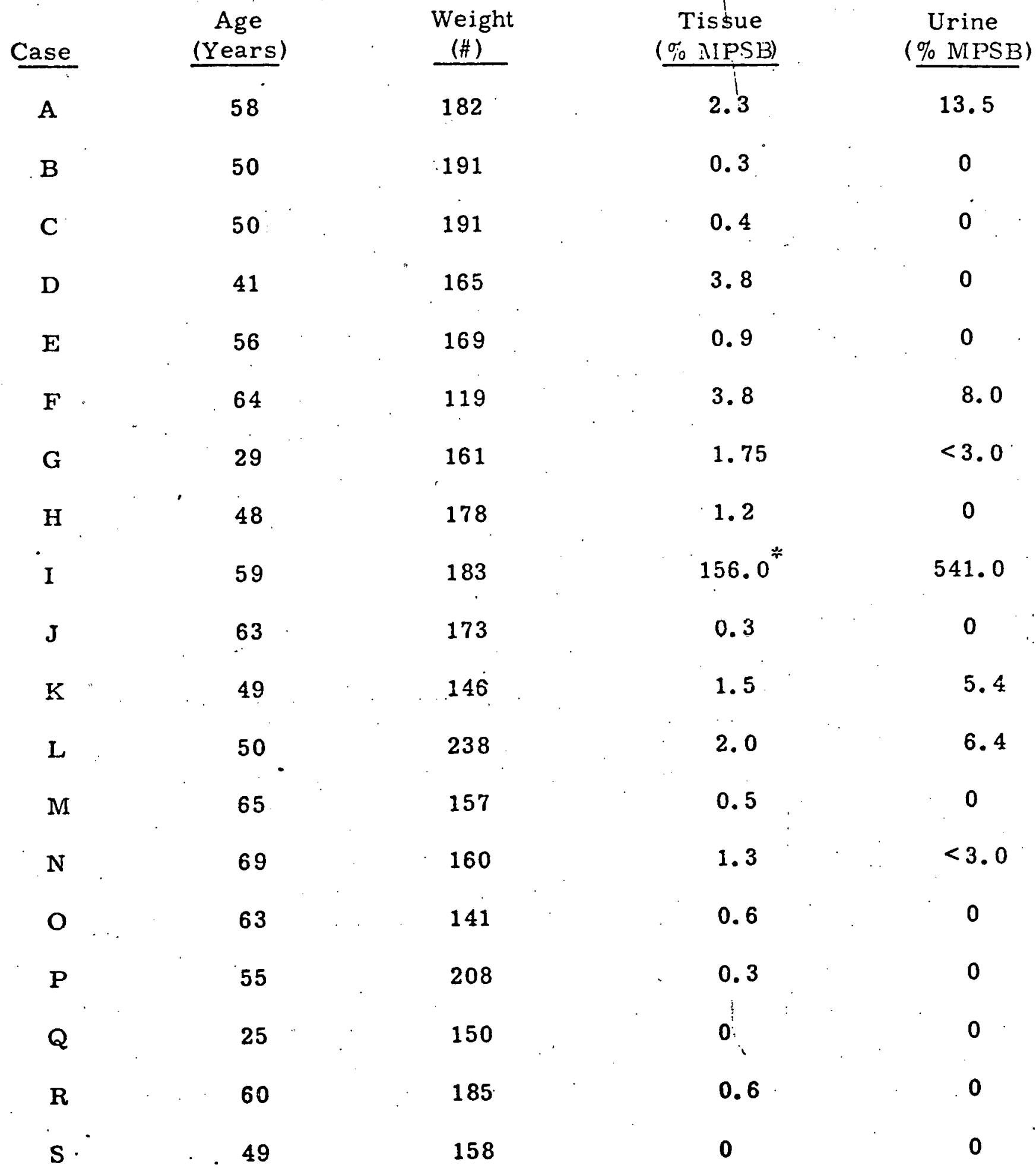

* Reported as 177 with lung included (10) 